\title{
$W\left(O^{\text {World Journal of }}\right.$ Orthopedics
}

Online Submissions: http:/ / www.wjgnet.com/esps/

Help Desk: http:/ / www.wjgnet.com/esps/helpdesk.aspx DOI: 10.5312/wjo.v5.i4.512
World J Orthop 2014 September 18; 5(4): 512-515

ISSN 2218-5836 (online)

(C) 2014 Baishideng Publishing Group Inc. All rights reserved.

WJO $5^{\text {th }}$ Anniversary Special Issues (10): Rheumatoid arthritis

\section{Arthrodesis of the wrist in rheumatoid arthritis}

\author{
Klemens Trieb
}

Klemens Trieb, Department of Orthopaedics, Medical Director, Klinikum Wels, 4600, Austria

Author contributions: Trieb K designed and wrote the review. Correspondence to: Klemens Trieb, Professor, Head of the Orthopaedic Department, Department of Orthopaedics, Medical Director, Grieskirchnerstr 42, Klinikum Wels, 4600,

Austria. klemens.trieb@klinikum-wegr.at

Telephone: +43-72-4241592308 Fax: +43-72-424153938

Received: December 29, 2013 Revised: March 29, 2014

Accepted: June 27, 2014

Published online: September 18, 2014

\begin{abstract}
In rheumatoid arthritis the small joints of the feet and hands are the first targets of the autoimmune process. In about one half of the patient the wrist is involved in the first stages of the disease (two years) increasing up to nearly 90 percent after a decade often including both sides. Osteoarthritis of the wrist is one of the most common conditions encountered by hand surgeons. One aim of all treatment options is to achieve the best possible hand function without pain. If conservative treatment fails, operative treatment is necessary. Choice of surgical treatment depends on the soft tissue and bone situation. Techniques can be differentiated by joint preservation or joint replacement. The first include radio-synoviorthesis, synovectomy and tendon repair, the latter resection-arthroplasty, total joint arthroplasty and arthrodesis. In this paper arthrodesis of the wrist as one treatment option is reviewed.
\end{abstract}

(c) 2014 Baishideng Publishing Group Inc. All rights reserved.

Key words: Arthritis; Rheumatoid; Wrist; Treatment; Surgical; Arthrodesis

Core tip: This paper discusses the pathophysiology of wrist destruction due to rheumatoid arthritis. A short overview of different treatment options is given with a special reflect on wrist arthrodesis, surgical techniques and outcomes are presented.
Trieb K. Arthrodesis of the wrist in rheumatoid arthritis. World $J$ Orthop 2014; 5(4): 512-515 Available from: URL: http://www. wjgnet.com/2218-5836/full/v5/i4/512.htm DOI: http://dx.doi. org/10.5312/wjo.v5.i4.512

\section{INTRODUCTION}

\section{The natural course of joint arthritis}

If once the inflammatory cascade is activated progressive autoimmune mediated joint destruction is the result. Joints are affected by immune cell mediated inflammation of the soft tissue which is progressive and with the time affects the bone, too. It starts with swelling and stiffness of small joints in the morning, postive blood tests and pain. The disease can be associated with rheumatic nodules in one fifth oft he patients in combination with postive rheuma factors. The disease is classified by American Rheumatoid Association, which enables dignostis and therapy and is based on a disease period of more than six weeks ${ }^{[1]}$. The course oft he disease can vary from patient to patient. Self limiting forms are possible, but if not joint destruction is the result. First targets oft he autoimmune system are the small joints of the feet and hands (Figure 1). In about one half of the patient the wrist is involved in the first stages oft he disease (two years) increasing up to nearly 90 percent after a decade often including both sides. Many social impairments such as long illness periods and loss of employment are the result in many cases $^{[2-6]}$.

\section{RADIOLOGICAL CLASSIFICATIONS FOR RHEUMATOID ARTHRITIS}

Due to arthritis and soft tissue inflammation pathological changes can be diagnosed and classified radiologically. The pathologies include bone and cartilage and result in periarticular sclerosis, metaphyseal osteoporosis and bone cystes, cartilage loss and consecutive joint space loss and instability. Different classifications are available, three of 
Table 1 Radiographic classification of rheumatic changes according to Larsen

\begin{tabular}{lc}
\hline X-ray findings & Larsen scoring \\
\hline No pathologic changes & 0 \\
Osteoporosic bone, soft tissue swelling & 1 \\
Narrowing of joint spaces, bony erosions & 2 \\
Increased erosions, bony destructions & 3 \\
Joint spaces diminished, significant bone destruction & 4 \\
Joint mutilation, ankylosis od the wrist & 5 \\
\hline
\end{tabular}

Table 2 The wrightington classification for wrist destruction in arthritis

\begin{tabular}{lcc}
\hline Scoring & Radiographic signs & Therapeutic suggestion \\
\hline 1 & Osteoporosis, cystic erosions & Synovial tissue resection \\
2 & Instability of the carpus & $\begin{array}{c}\text { Soft tissue procedures or } \\
\text { limited arthrodesis }\end{array}$ \\
3 & Bone destruction, subluxation & Arthroplasty or arthrodesis \\
4 & Severe radial destruction & Arthrodesis \\
\hline
\end{tabular}

them are presented here. The Larsen classification describes five different stages of bone and cartilage changes (Table 1) ${ }^{[7]}$. The Wrightington classification is a combination radiological classification with regard to therapy describing four different groups (Table 2$)^{[8]}$. Simmen et a ${ }^{[9]}$ classified arthritic changes with respect to progression and is based on stability of bone and soft tissue.

The first type is the ankylosing, the second describes changes due to arthritic and arthritic destruction and the third type describes instability and disintegration, which needs bony stabilisation in the case of progression.

\section{CLINICAL PRESENTATION}

The autoimmune disease can affect all tissues, therefore a careful examination of the patient including all regions should be the first step of the orthopaedic evaluation. The patients history including the onset and expression of different typical symptoms such as swollen, painful, overwarmed, stiff, weak, red or numb changes are evaluated. The nature and character and location of the findings should be noted. The first examination should include the activity level of the patient, the social sourrounding and employment using one of the generally accepted scores for objective documentation of disease stage ${ }^{[10-12]}$. All medication, including corticosteroid application, immunosuppressive therapy and non-steroidal anti-inflammatory drugs and therapy history are documented. All other diseases should be kept in mind, this can be vascular impairment, diabetes mellitus and all inner organs. The so called "fifth extremity" of the patients, the cervical spine can be affected as often as other joints and can present instability, myelopathy due to compression can result in extremity pathology. In this is the case examination of nerve conduction velocity and electromyography are recommended before joint surgery. Clinical evaluation of the status of the upper and lower extremity include gait analysis, range of motion, test of
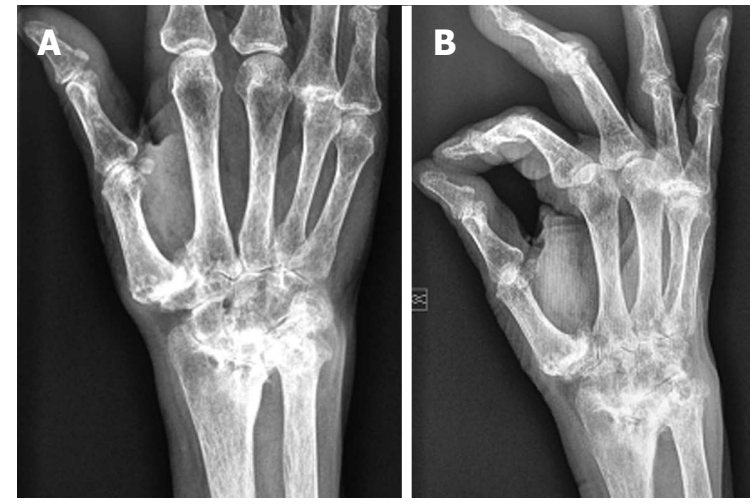

Figure $1 \mathrm{X}$-ray showing a rheumatoid hand, note axial deviation of the wrist and severe destruction. A: a.p.; B: lateral view.

grip strength. Vascular status or signs of vasculitis should be addressed before surgery to avoid wound complications.

\section{SURGICAL TREATMENT}

If the joint disease progressis for more than three months of medical treatment the rheumatologist should consult an orthopaedic surgeon. If conservative treatment, such as physiotherapy or ergotherapy fails, operative treatment is necessary. One aim of all treatment options is to achieve the best possible hand function without pain. One aim of all treatment options is to achieve the best possible hand function without pain ${ }^{[3,5,6]}$. Time point for surgery is sometimes discussed controversial, the same is for order of joints started with. This could be for an extremity from proximal to dista or the most affected joint first.

All different options for surgical treatment base on the situation of bone and soft tissue destruction. Basicly two approaches can be differentiated: joint preservation and joint replacement. If cartilage and ligaments are functional present a joint preserving technique should always be used. As a first approach synovectomy of the wrist is recommended and may be combined with soft tissue procedures. When the synovia is removed the target of the autoimmune reaction is removed and in the best case pain and swelling diminish and further joint destruction is prevented. If tendon rupture is associated with arthritis repair must be done in all cases. For extensor tendons different replacing methods exist: they include different transfers from one extensor tendon to another or free grafts. In the case of flexor tendon rupture of the thumb arthrodesis of the distal joint is recommended. Transfer or relocation of tendons are necessary to restore hand function and stability and therefore preventing further progression $^{[3,13,14]}$.

Due to hygienic reasons simultaneous surgery of both hands should be avoided. Surgery of the wrist and proximal or distal joints (for instance the elbow or finger joints) should be avoided because of the risk of extensive swelling and wound healing problems. The same is true for the lower extremity because of limited mobilisation 


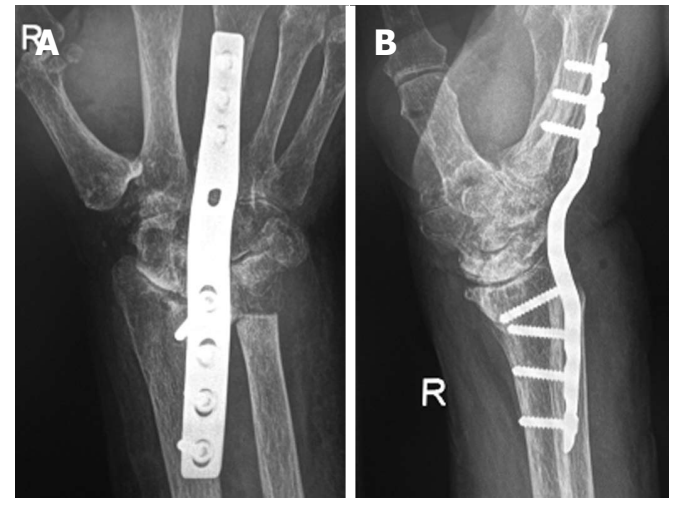

Figure 2 Postoperative X-ray after wrist arthrodesis of the hand seen in Figure 1. A: a.p.; B: Lateral view.

postoperatively. For this reason surgery of the lower extremity first is recommended ${ }^{[12]}$.

\section{WRIST ARTRODESIS IN RHEUMATOID}

\section{ARTHRITIS}

For patients with advanced arthritic changes, wrist fusion is a well-established, safe and reliable method. Several different operative techniques including intramedullary rods or plates for wrist fusion have been retrospectively analysed in long-term studies ${ }^{[15,16]}$. Osteosynthesis utilising a Rush pin was first described in 1965 by Clayton and was modified in 1971 by Mannerfelt ${ }^{[17,18]}$. Plate osteosynthesis was introduced by Mueller in 1961 and the original concept was modified in the 1980s with the development of dynamic compression plates which became widely used and have been shown to achieve good primary stability (Figure 2) ${ }^{[19,20]}$

The position of the fusion remains a matter of debate. In literature, there is a trend towards moderate extension and ulnar abduction. Nevertheless, some surgeons prefer the neutral position which maintains finger balance and allows for better pronation and supination, thus preserving sufficient muscular strength ${ }^{[15,17]}$. A recent study suggests no statistical difference for position of Mannerfelt arthrodesis in 34 wrists ${ }^{[21]}$. Another new study on follow up of 93 wrists with Mannerfelt arthrodesis describes this method as an alternative to plate arthrodesis with regard to its good results ${ }^{[22]}$. For bilateral fusions, it has been recommended to stabilise one side in some flexion and the other in some extension ${ }^{[23]}$. We compared two methods for arthrodesis, plate and pin fixation, and found comparable clinical outcome with regard to pain and fuction. Subjective satisfaction and strength of grip were higher in the plate group ${ }^{[24]}$. Despite regained strength and high patient satisfaction, some disadvantages of the fusion have to be considered and which were also observed in our study. Impaired precision mechanics, such as difficulties in performing personal hygiene functions, as well as handling coins and buttons, are the most frequently stated limitations of wrist fusion ${ }^{[24-26]}$. To overcome these limitations, alternative treatment strategies, in- cluding proximal row carpectomy and arthroplasty, have been developed. In conclusion, despite the advances in wrist arthroplasty, wrist fusion represents the method of choice in the treatment of the significant destructed wrist due to rheumatoid arthritis. One aim of this option is to re-establish wrist stability, permitting activities of daily life, to achieve painlessness, and ultimately to improve the quality of life. In selecting the fusion method, the surgeon should consider the need for possible additional surgeries, the quality of the local bone stock, as well as the grade of luxation of the wrist. A comparison of different fixation methods in four studies did not show any differences with regard to surgical technique. Prior to performing the procedure, the planned position of the fusion should be discussed with the patient to address the individual needs ${ }^{[23-30]}$. Reflecting the long experience and published results, arthrodesis of the wrist is still one of the golden treating standards.

\section{REFERENCES}

1 Arnett FC, Edworthy SM, Bloch DA, McShane DJ, Fries JF, Cooper NS, Healey LA, Kaplan SR, Liang MH, Luthra HS. The American Rheumatism Association 1987 revised criteria for the classification of rheumatoid arthritis. Arthritis Rheum 1988; 31: 315-324 [PMID: 3358796 DOI: 10.1002/ art.1780310302]

2 Shapiro JS. The wrist in rheumatoid arthritis. Hand Clin 1996; 12: 477-498 [PMID: 8842714]

3 Trieb K. Treatment of the wrist in rheumatoid arthritis. J Hand Surg Am 2008; 33: 113-123 [PMID: 18261675 DOI: 10.1016/j.jhsa.2007.09.011]

4 Trieb K, Hofstaetter S. The wrist in inflammatory arthritis. Techn in Orthop 2009; 24: 8-12 [DOI: 10.1097/ BTO.0b013e3181a32a36]

5 Trieb K, Hofstaetter SG. Treatment strategies in surgery for rheumatoid arthritis. Eur J Radiol 2009; 71: 204-210 [PMID: 19577394 DOI: 10.1016/j.ejrad.2009.04.050]

6 Chiari-Grisar C, Koller U, Stamm TA, Wanivenhaus A, Trieb K. Performance of the disabilities of the arm, shoulder and hand outcome questionnaire and the Moberg picking up test in patients with finger joint arthroplasty. Arch Phys Med Rehabil 2006; 87: 203-206 [PMID: 16442973 DOI: 10.1016/ j.apmr.2005.10.007]

7 Larsen A, Dale K, Eek M. Radiographic evaluation of rheumatoid arthritis and related conditions by standard reference films. Acta Radiol Diagn (Stockh) 1977; 18: 481-491 [PMID: 920239]

8 Hodgson SP, Stanley JK, Muirhead A. The Wrightington classification of rheumatoid wrist $X$-rays: a guide to surgical management. J Hand Surg 1989; 14-B: 451-455 [DOI: 10.1016/ 0266-7681(89)90168-X]

9 Simmen BR, Huber $H$. The wrist joint in chronic polyarthritis--a new classification based on the type of destruction in relation to the natural course and the consequences for surgical therapy. Handchir Mikrochir Plast Chir 1994; 26: 182-189 [PMID: 7926987]

10 James D, Young A, Kulinskaya E, Knight E, Thompson W, Ollier W, Dixey J. Orthopaedic intervention in early rheumatoid arthritis. Occurrence and predictive factors in an inception cohort of 1064 patients followed for 5 years. Rheumatology (Oxford) 2004; 43: 369-376 [PMID: 14722346 DOI: 10.1093/rheumatology/keh059]

11 Wolfe F, Zwillich S. The long-term outcomes of rheumatoid arthritis. Arthritis Rheum 1998; 41: 1072-82 [DOI: 10.1002/152 9-0131(199806)41: 6<1072::AID-ART14>3.0.CO;2-G] 
12 Trieb K. Management of the foot in rheumatoid arthritis. J Bone Joint Surg Br 2005; 87: 1171-1177 [PMID: 16129737 DOI: 10.1302/0301-620X.87B9.16288]

13 Thirupati R, Ferlic D, Clayton M. Dorsal wrist synovectomy in rheumatoid-arthritis: a long-term study. J Hand Surg 1983; 8-A: 848-856 [DOI: 10.1016/S0363-5023(83)80080-X]

14 Nalebuff EA. Surgical treatment of tendon rupture in the rheumatoid hand. Surg Clin North Am 1969; 49: 811-822 [PMID: 5793257]

15 Rehak DC, Kasper P, Baratz ME, Hagberg WC, McClain E, Imbriglia JE. A comparison of plate and pin fixation for arthrodesis of the rheumatoid wrist. Orthopedics 2000; 23: 43-48 [PMID: 10642000]

16 Howard AC, Stanley D, Getty CJ. Wrist arthrodesis in rheumatoid arthritis. A comparison of two methods of fusion. J Hand Surg 1993; 18-B: 377-380 [DOI: 10.1016/0266-7681(93)90068-Q]

17 Clayton ML, Smyth CJ. Surgery for rheumatoid arthritis. New York: Churchill Livingstone, 1992: 182-185

18 Mannerfelt L, Malmsten M. Arthrodesis of the wrist in rheumatoid arthritis. J Plast Recontr Surg 1971; 5: 124-130 [DOI: 10.3109/02844317109042952]

19 Müller ME, Allgöwer M, Willenegger H. Manual der Osteosynthese, AO Technik. New York : Springer, Berlin-Heidelberg, 1969 [DOI: 10.1007/978-3-662-00035-9]

20 Levignac J, Heim JL, Berge M. Place and limits of surgery: development of esthetic concepts. Bull Acad Natl Chir Dent 1982-1983; (28): 53-68 [PMID: 6964960 DOI: 10.1007/978-3-64 2-96672-9_5]

21 Lautenbach M, Millrose M, Langner I, Eisenschenk A. Results of Mannerfelt wrist arthrodesis for rheumatoid arthritis in relation to the position of the fused wrist. Int Orthop 2013; 37: 2409-2413 [PMID: 23955819 DOI: 10.1007/ s00264-013-2063-6]

22 Kluge S, Schindele S, Henkel T, Herren D. The modified
Clayton-Mannerfelt arthrodesis of the wrist in rheumatoid arthritis: operative technique and report on 93 cases. J Hand Surg Am 2013; 38: 999-1005 [PMID: 23618456 DOI: 10.1016/ j.jhsa.2013.02.029]

23 Rauhaniemi J, Tiusanen H, Sipola E. Total wrist fusion: a study of 115 patients. J Hand Surg Br 2005; 30: 217-219 [PMID: 15757778 DOI: 10.1016/j.jhsb.2004.11.008]

24 Toma CD, Machacek P, Bitzan P, Assadian O, Trieb K, Wanivenhaus A. Fusion of the wrist in rheumatoid arthritis: a clinical and functional evaluation of two surgical techniques. J Bone Joint Surg Br 2007; 89: 1620-1626 [PMID: 18057363]

25 Barbier O, Saels P, Rombouts JJ, Thonnard JL. Longterm functional results of wrist arthrodesis in rheumatoid arthritis. J Hand Surg 1999; 24-B: 27-31 [DOI: 10.1016/ S0266-7681(99)90015-3]

26 Solem H, Berg NJ, Finsen V. Long term results of arthrodesis of the wrist: a 6-15 year follow up of 35 patients. Scand J Plast Reconstr Surg Hand Surg 2006; 40: 175-178 [PMID: 16687338 DOI: 10.1080/02844310500453716]

27 Houshian S, Schrøder HA. Wrist arthrodesis with the AO titanium wrist fusion plate: a consecutive series of 42 cases. J Hand Surg Br 2001; 26: 355-359 [PMID: 11469839 DOI: 10.1054/jhsb.2001.0600]

28 Christodoulou L, Patwardhan MS, Burke FD. Open and closed arthrodesis of the rheumatoid wrist using a modified (Stanley) Steinmann pin. J Hand Surg Br 1999; 24: 662-666 [PMID: 10672799 DOI: 10.1054/jhsb.1999.0289]

29 Pech J, Sosna A, Rybka V, Pokorný D. Wrist arthrodesis in rheumatoid arthritis. A new technique using internal fixation. J Bone Joint Surg Br 1996; 78: 783-786 [PMID: 8836071]

30 Vahvanen V, Tallroth K. Arthrodesis of the wrist by internal fixation in rheumatoid arthritis: a follow-up study of fortyfive consecutive cases. J Hand Surg 1984; 9-A: 531-536 [DOI: 10.1016/S0363-5023(84)80105-7]

P- Reviewer: Garip Y S- Editor: Ji FF L- Editor: A E- Editor: Wu HL

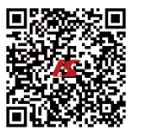




\section{DS \\ Baishideng ${ }^{\circledR}$}

Published by Baishideng Publishing Group Inc

8226 Regency Drive, Pleasanton, CA 94588, USA

Telephone: +1-925-223-8242

Fax: +1-925-223-8243

E-mail: bpgoffice@wignet.com

Help Desk: http://www.wjgnet.com/esps/helpdesk.aspx

http://www.wjgnet.com

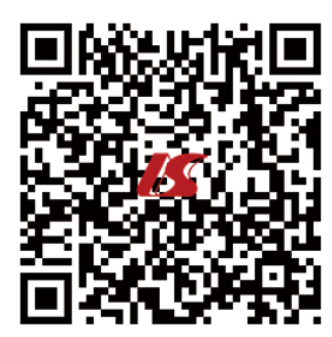

